\title{
An unusual source of lead exposure in a precious metal assay worker
}

\author{
A MARGARET SAMUEL AND P J BAXTER \\ From the Employment Medical Advisory Service (London $N$ Region), Health and Safety Executive, Barking, \\ Essex IGI1 8HF, UK
}

The first indication of a lead hazard at a firm of precious metal assayers was the finding of a raised blood lead concentration in an employee who had been tested as part of a general health check. Three other workers were subsequently found to have raised lead concentrations also, one a 43 year old woman whose job in a chemical balance room entailed weighing out gram quantities of ore and adding these to bags of a flux containing lead. As it was not obvious how the woman was receiving substantial lead exposure the Employment Medical Advisory Service investigated further.

\section{Methods and results}

The firm performed assays of ore for gold and silver content as follows:

Flux mixing - The flux was a mixture of lead oxide (litharge), borax, and sodium carbonate that was weighed out and mixed in a separate room provided with local exhaust ventilation.

Flux bagging-Specified quantities of flux were then weighed out into paper bags in a corner of the furnace room (no local exhaust ventilation), and the bags were transferred to the balance room.

Addition of ore in balance room-The woman weighed out on to a watch glass the prescribed quan- tity of ore which was then tipped into a space she had created in the centre of a bag of flux using a spatula. No local extraction was provided.

Cupellation-The flux/ore mixture was then transferred to lidded crucibles and heated in a furnace under suitable exhaust ventilation. The lead alloy produced was sent for analysis.

The table shows the results of blood testing and air sampling for lead on three of the workers with raised blood lead concentrations. Personal air sample levels $\overrightarrow{0}$ were all in excess of the lead in air standard $\%$ $\left(0 \cdot 15 \mathrm{mg} / \mathrm{m}^{3}\right){ }^{1}$ The static (background) level in the balance room was low. The raised blood lead concentrations in the two male workers were attributed to lead dust arising during weighing and mixing of the flux. The clue to the high exposure in the woman, who otherwise adopted strict hygiene precautions, was a black patch on her white protective coat (fig 1). Observation of her work practices showed that after tipping out the ore into a bag of flux she then removed traces of the ore adhering to the watch glass using a small camel hair brush. The brush and then the spatula, which had become contaminated with lead when dipped into the bag of flux, were deftly wiped clean on her overall after use (fig 2), resulting in small quantities of dust from the lead flux being flicked into her breathing zone.

Results of blood tests and air sampling for lead in the three workers under investigation

\begin{tabular}{|c|c|c|c|}
\hline \multirow[t]{2}{*}{$J o b$} & \multirow{2}{*}{$\begin{array}{l}\text { Blood lead* } \\
(\mu \mathrm{g} / 100 \mathrm{ml})\end{array}$} & \multicolumn{2}{|c|}{ Lead in air $\left(\mathrm{mg} / \mathrm{m}^{3}\right)$} \\
\hline & & Personal & Static \\
\hline $\begin{array}{l}\text { Flux mixing, bagging, and cupellation: } \\
\text { Man } 1 \\
\text { Man } 2 \\
\text { Adding ore in balance room: } \\
\text { Woman (case) }\end{array}$ & $\begin{array}{l}63 \\
42 \\
58\end{array}$ & $\begin{array}{l}0.39 \\
0.16 \\
0.38\end{array}$ & $\begin{array}{l}0.2 \\
0.02\end{array}$ \\
\hline
\end{tabular}




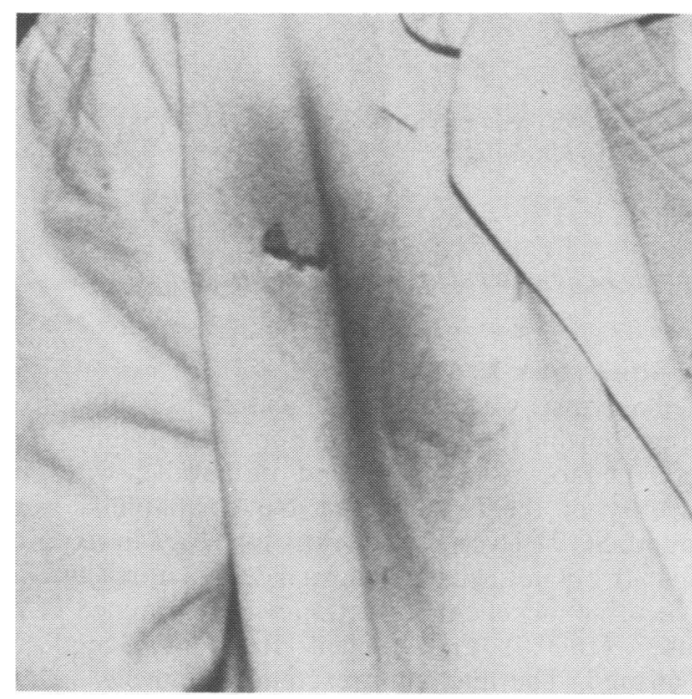

Fig 1 Dirty area on white coat clue to source of exposure.

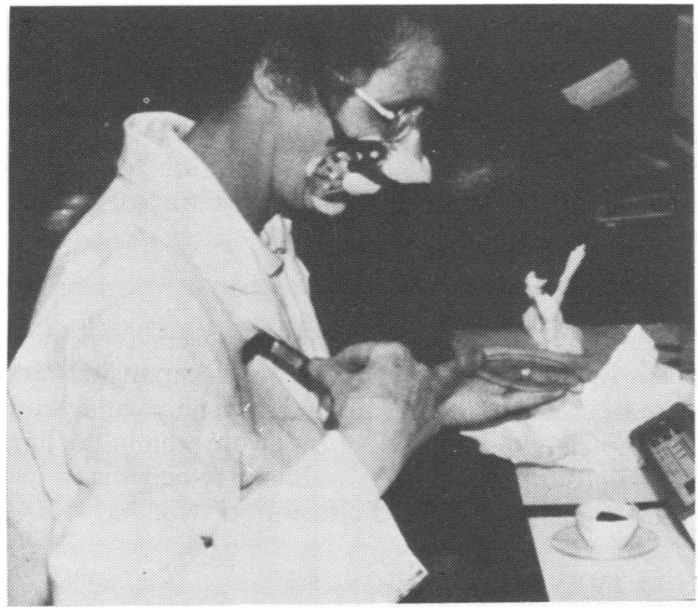

Fig 2 Woman holding watch glass and cleaning brush on white coat. Paper bags of flux in background.

\section{Comment}

Exposure to gram quantities of lead powder in a balance room would not be immediately considered a significant source of lead exposure as defined in the UK code of practice, ${ }^{1}$ but a blood lead analysis indicated otherwise. In this subject a seemingly innocuous method of cleaning her spatula and brush on her overall had given rise to substantial lead exposure, with her blood lead concentrations exceeding $40 \mu \mathrm{g} / 100 \mathrm{ml}$, the current suspension level for women of childbearing age set for the protection of the fetus. ${ }^{1}$ She herself was not suspended from lead work as she had recently had a hysterectomy. The situation in this firm was soon rectified with the further installation of local exhaust extraction and modification of work practices. We have reported elsewhere the need for blood lead analyses in workplaces where lead is handled, even though a hazard is not immediately obvious. $^{2}$ This case history serves as a reminder of the additional need for the close observation of work practices to be incorporated in such workplace assessments.

We thank Mr D J Reeves-Serby, HM chemical inspector, for performing air sampling, the HSE Occupational Medicine and Hygiene Laboratories for the blood lead measurements, and the management and employees of the firm for their kind cooperation.

\section{References}

${ }^{1}$ Health and Safety Commission. Control of lead at work: approved code of practice. London: HMSO, 1980.

${ }^{2}$ Baxter PJ, Samuel AM, Holkham MPE. Lead hazard in British stained glass workers. $\mathrm{Br} \mathrm{Med} J$ 1985;291:383. 